\title{
PERANCANGAN KAWASAN DENGAN SISTEM RAINWATER HARVESTING DI KEBON MELATI TANAH ABANG
}

\author{
Rendy, Santoni \\ Arsitektur, Fakultas Desain, Universitas Pelita Harapan \\ Email: rendy20vp@gmail.com, santoni.sod@uph.edu
}

\begin{abstract}
Abstrak
Padatnya jumlah penduduk di Kota Jakarta menyebabkan tatanan kota menjadi tidak terkendali dan memberikan dampak negatif terhadap daerah aliran sungai. Oleh sebab itu, penelitian ini bertujuan untuk mengungkapkan apa saja kriteria perancangan kawasan dengan sistem rainwater harvesting dan bagaimana merancang kawasan pemukiman di Kebon Melati, Tanah Abang dengan sistem rainwater harvesting. Metode penelitian yang digunakan adalah studi literatur, observasi lapangan, dan wawancara. Solusi yang diusulkan dalam perancangan ini adalah merancang kawasan dengan empat potensi penerapan teori perancangan kota yaitu land use yang terkait dengan storage, dan jalur drainase. Kedua, sirkulasi kendaraan dan jalur pejalan kaki yang terkait dengan celah pembatas jalan dan material berpori. Ketiga, bentuk dan massa bangunan yang terkait dengan catchment area, conveyance, dan green roof. Keempat, ruang terbuka yang terkait dengan water retention basin. Dengan adanya perancangan ini dapat disimpulkan bahwa kawasan Kebon Melati dapat mengolah dan memperlambat aliran air hujan.
\end{abstract}

Kata kunci: perancangan kawasan, active rainwater harvesting, passive rainwater harvesting

\begin{abstract}
Title: Design of Rainwater Harvesting District at Kebon Melati Tanah Abang

Jakarta's dense population has caused a disorder in the urban system by negatively impacting its streams. Therefore, this research aims to find out the urban district design criterias with rainwater harvesting system and how to implement them in residential areas of Kebon Melati, Tanah Abang. Data collecting techniques used in this research include literature studies, field observation, and interviews. The proposed solution to Jakarta's rainwater problems is to design a district which incorporates the four potential urban design theory applications into it. The first theory is about land use related to storage and drainage system. The second theory is about vehicle circulation and pedestrian paths related to roadblock gaps and permeable materials. The third theory is about building mass and shape related to catchment area, conveyance, and green roof. The last theory is about open spaces related to water retention basins. The goal of this urban district design is to develop and decrease the speed of rainwater flow in Kebon Melati.
\end{abstract}

Keywords: urban design, active rainwater harvesting, passive rainwater harvesting

\section{Pendahuluan}

Masalah pada lingkungan yang dihadapi Kota Jakarta cukup banyak dan rumit. Meningkatnya jumlah penduduk mengakibatkan perubahan yang berdampak buruk pada kota Jakarta. Contoh - contoh dari perubahan tersebut ialah rawa - rawa tertutup, tanah kosong terbangun dengan segala macam 
bangunan, hutan - hutan di daerah aliran sungai berkurang karena aktivitas manusia, dan akhirnya terciptalah kondisi alam Kota Jakarta yang kita kenal sekarang ini (Bianpoen 2011). Sebagai ibu kota dari sebuah negara yang cukup besar, Jakarta menjadi kota tujuan dari berbagai kota lainnya di Negara Indonesia. Jumlah penduduk terus meningkat tiap tahunnya sedangkan pembangunan dalam kota terbilang lambat sehingga tidak dapat mengimbangi banyaknya penduduk yang ada. Akibatnya, permukiman liar dan kumuh bermunculan sehingga tatanan kota menjadi rusak dan tak terkendali. Seluruh tanah kosong dibangun menjadi tempat tinggal. Hilangnya lahan kosong menjadikan air menjadi masalah yang dihadapi sebuah kota terutama air hujan.

Permasalahan air memang sudah dirasakan sejak lama, Angelakis (2014) mengatakan pengolahan air sudah banyak dilakukan dalam sejarah sekitar 4500 tahun yang lalu bahkan. Chandrappa (2014) menambahkan bahwa air sangat lah esensial, karena makanan kita tidak dapat tumbuh jika bukan karena air dan banyak hewan hidup di dalam air.

Oleh karena itu, berdasarkan banyaknya masalah yang timbul karena air maka, konservasi air dan pengelolaan air hujan adalah dua perancangan berkelanjutan yang efektif bagi arsitek (Novak, Giesen dan Debusk, 2014). Adeyeye (2013) berpendapat air meruapakan batu utama dalam sebuah kehidupan, seperti laut, sungai, danau dan sumber air lainnya. Peranan Sungai Ciliwung sebagai salah satu sungai besar di Kota Jakarta mengakibatkan dampak buruk bilamana sungai tersebut tidak berfungsi dengan baik. Salah satu contoh dampak buruk yang dapat dihasilkan adalah bencana banjir yang melanda kota Jakarta. Buruknya sistem aliran sungai dalam mengalirkan air dalam kota menuju laut atau tempat penampungan air lainnya membuat volume air saat terjadi hujan meluap dan ketinggian airnya melebihi batas permukaan tanah sehingga menyebabkan banjir serta kerusakan pada infrastruktur dalam kota (Bianpoen, 2011).

Berdasarkan latar belakang di atas, muncul beberapa pertanyaan penelitian, sebagai berikut:

1. Apa saja kriteria perancangan kawasan dengan sistem rainwater harvesting?

2. Bagaimana merancagan kawasan pemukiman di Kebon Melati, Tanah Abang dengan sistem rainwater harvesting?

Berdasarkan rumusan masalah di atas maka tujuan dalam penulisan makalah ini adalah untuk mengetahui apa saja kriteria perancangan kawasan dengan sistem rainwater harvesting dan menganalisis kondisi tapak pada site terpilih. Data - data tersebut akan menjadi panduan dalam merancang kawasan permukiman di Kebon Melati, Tanah Abang dengan sistem rainwater harvesting. Hasil akhir dari penelitian ini adalah rancangan kawasan yang terintegrasi dengan sistem active / passive rainwater harvesting dalam kota sehingga dapat memberikan dampak positif bagi kota itu sendiri serta lingkungan di sekitarnya. Manfaat lain yang diharapkan dari perancangan kota ini adalah menyelesaikan permasalahan terkait dengan air pada kawasan permukiman di bantaran Sungai Ciliwung sehingga fungsi yang ada pada sungai dapat berkembang dan bermanfaat bagi penghuni kawasan dan 
masyarakat yang tinggal di lingkungan sekitarnya.

\section{Metode}

Pada perancangan kawasan ini terdapat tiga teori landasan dalam proses perancangan yaitu smart sustainable city, water sustainable city, dan teori perancangan kota. Teori - teori perancangan kawasan yang ada dikaitkan dengan teori selanjutnya yaitu teori sistem active rainwater harvesting dan passive rainwater harvesting. Sustainable city merupakan kota berkelanjutan yang dirancang dengan berbagai macam pertimbangan terhadap dampaknya di dalam kota maupun pada lingkungan di sekitarnya (Berardi, 2013). Perubahan iklim berdapam juga kepada siklus air (Grant, 2016). Kehidupan di bumi tidak bisa berlangsung tanpa adanya air. Air menjadi sumber daya terbatas dan langka semakin dihargai, bahkan di daerah dimana sumber daya air berlimpah Contoh usaha yang dapat diterapkan untuk mengatasi masalah sumber daya air bersih yang dibutuhkan manusia adalah proses daur ulang air limbah dan pengelolaan air hujan (Adeyeye 2014).

Di dalam proses merancang sebuah kota, perlu dipahami beberapa elemen dasar yang dapat menghasilkan tatanan kota yang teratur dan berfungsi dengan baik. Teori perancangan kota menurut Hamid Shirvani (1985) yang digunakan dalam proses perancangan adalah:

1. Tata guna lahan (land use)

Tata guna lahan merupakan rancangan dua demensi berupa denah peruntukan lahan dalam sebuah kota.
2. Bentuk dan massa bangunan (building form and massing)

Elemen ini membahas bagaimana bentuk dan massa - massa bangunan yang ada dapat membentuk suatu kota serta bagaimana hubungan antar massa bangunan yang ada.

3. Sirkulasi dan parkir (circulation and parking)

Sirkulasi merupakan elemen perancangan kota yang secara langsung dapat membentuk dan mengatur pola kegiatan kota seperti keberadaan sistem transportasi, jalur pedestrian, dan tempat - tempat transit yang saling berhubungan.

4. Ruang terbuka (open space)

Berbicara tentang ruang terbuka selalu menyangkut lansekap. Ruang terbuka biasanya berupa lapangan, jalan, sempadan sungai, taman, dan sebagainya.

5. Jalur pejalan kaki (pedestrian ways) Elemen ini harus dibantu dengan interaksinya terhadap elemen elemen dasar desain tata kota dan harus berkaitan dengan lingkungan kota dan pola - pola aktivitas yang ada.

Rainwater harvesting bisa menjadi jawaban atas permasalahan yang timbul akibat terbatasnya sumber daya air. Rainwater Harvesting (RWH) menurut Booth (2014) merupakan penampungan dan penggunaan air kembali yang seharusnya terbuangkan. Pendapat lain mengatakan RWH merupakan salah satu solusi yang dapat diterapkan dalam perancangan perkotaan dengan dasar pengelolaan air hujan. Sistem ini dirancang untuk menampung dan mengalirkan air hujan menuju pengolahan untuk membantu menghasilkan air yang berguna bagi manusia. Air yang dihasilkan dapat 
berupa air minum (potable) dan air yang tidak layak minum(non-potable) (Kinkade-Levario, 2007). Rainwater harvesting terbagi menjadi dua sistem perancangan yaitu active rainwater harvesting dan passive rainwater harvesting (stormwater catchment). Di dalam perancangan aktif terdapat komponen - komponen dasar di dalam sistemnya seperti catchment area, conveyance, roof washing, storage, distribution, dan purification. Di sisi lain, passive rainwater harvesting berfungsi secara otomatis dan bersifat struktural di dalam kota (KinkadeLevario, 2007).

Active rainwater harvesting biasanya diterapkan pada bangunan dengan tujuan untuk pengolahan air hujan menjadi sumber air bersih bagi manusia. Di dalam penerapannya, terdapat empat komponen dasar dalam sistem rainwater harvesting aktif (Kinkade-Levario, 2007) yang diterapkan dalam proses perancangan, yaitu:

1. Catchment area. Merupakan permukaan dimana air hujan jatuh. Contohnya adalah atap bangunan atau wilayah terbuka dan mungkin pada bagian lansekap.

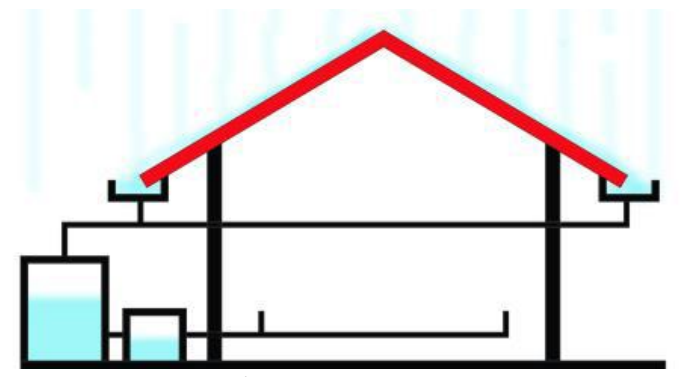

Gambar 1. Catchment area

Sumber: Hasil analisis, 2016

2. Conveyance. Saluran atau pipa yang mengangkut air dari catchment area menuju tempat penyimpanan (storage). Sistem ini biasanya berupa pipa yang dapat menyalurkan air.

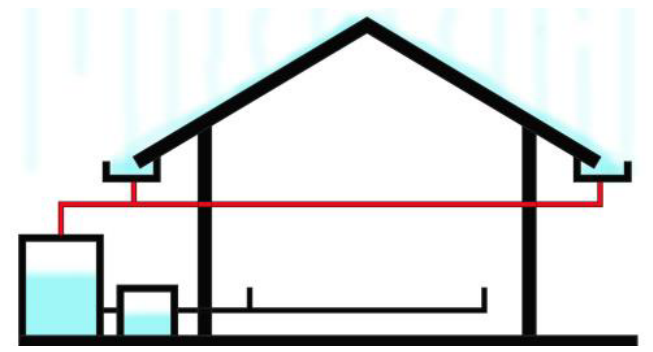

Gambar 2. Conveyance

Sumber: Hasil analisis, 2016

3. Roof washing. Merupakan sistem yang menyaring dan menghilangkan kontaminan dan puing - puing yang ikut mengalir pada air hujan. Sistem ini biasanya diterapkan sebagai instalasi tambahan yang ada pada catchment area sehingga air hujan yang jatuh pada permukaan langsung tersaring.

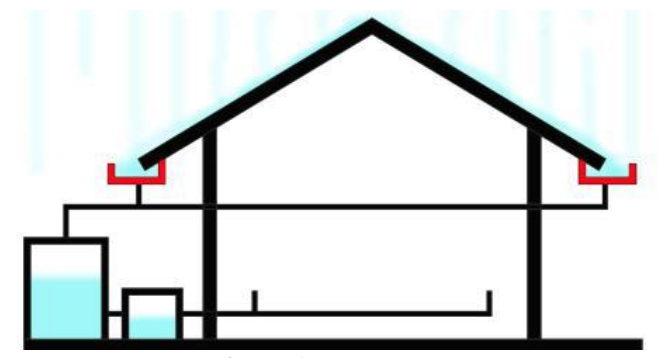

Gambar 3. Roof washing

Sumber: Hasil analisis, 2016

4. Storage. Tempat penyimpanan / penampungan air berupa tangki atau penampungan dimana air hujan dialirkan dan ditampung. Sistem ini dapat diterapkan dengan berbagai cara seperti tangki yang diletakan di bawah permukaan tanah dan tempat penampungan air terbuka di luar bangunan. 


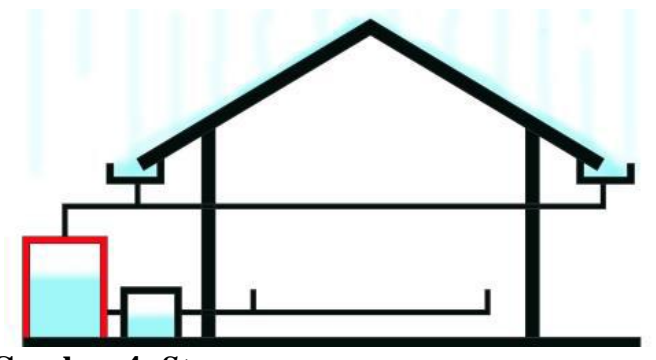

Gambar 4. Storage

Sumber: Hasil analisis, 2016

Passive rainwater harvesting berfungsi untuk merancang tatanan kota yang mampu membantu dalam memperlambat penyebaran air hujan di daratan sehingga tidak langsung mengalir menuju sungai atau tempat penampungan air lainnya seperti waduk (Kinkade-Levario, 2007). Terdapat beberapa contoh penerapan sistem ini dalam kota yang dapat digunakan sebagai landasan sehingga perancangan yang akan dilakukan dapat dikembangkan dari segi fungsi, sistem, dan komponen berdasarkan tapak yang spesifik, yaitu:

1. Pembuatan tempat penampungan air tambahan pada bagian lansekap (water retention basin) untuk menambah kapasitas air hujan yang dapat ditampung sementara sebelum mengalir menuju sungai.

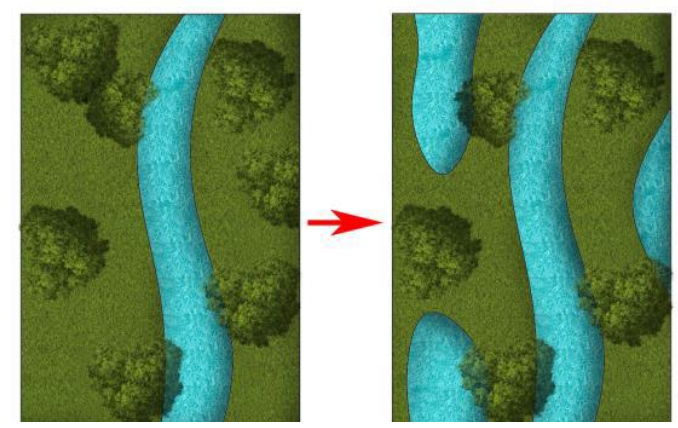

Gambar 5. Diagram pembuatan penampung air

Sumber: Hasil analisis, 2016

2. Pembuatan celah pada pembatas jalan. sistem ini bertujuan untuk mengalirkan air hujan dari jalan menuju wilayah hijau/lansekap untuk mengurangi resiko genangan air yang timbul saat berlangsungnya hujan dan memperlambat proses aliran air hujan menuju riol kota dan sungai.

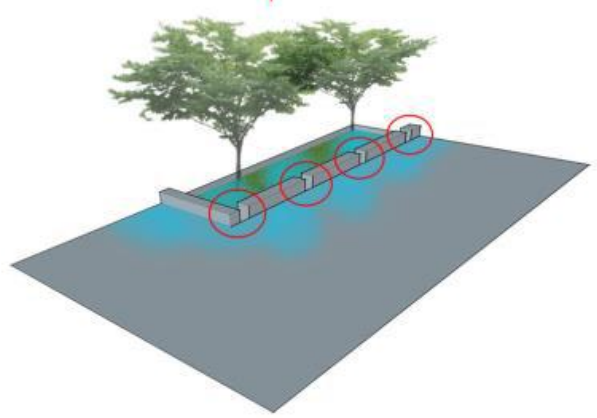

Gambar 6. Diagram pembuatan celah pada pembatas jalan

Sumber: Hasil analisis, 2016

3. Penggunaan material berpori (permeable) pada permukaan yang mempunyai luas cukup besar. Sistem ini juga dapat diterapkan di sepanjang jalur pejalan kaki dimana sistem ini berfungsi untuk menyerap air sementara selama hujan berlangsung sehingga resiko genangan air pada jalan berkurang.

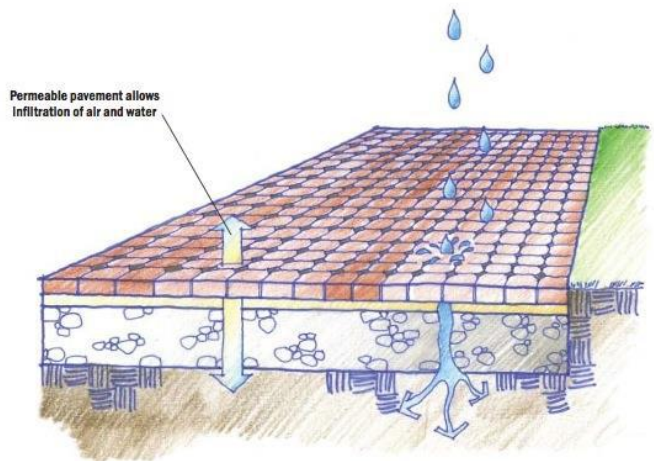

Gambar 7. Diagram penggunaan material berpori

Sumber: http://www.berkeleyside.com 
4. Membuat jalur drainase tambahan yang menghubungkan tiap wilayah sehingga dapat memperlambat proses mengalirnya air yang dialirkan langsung menuju sungai. Sistem ini dilakukan dengan cara membagi jalur drainase menjadi dua saluran yaitu saluran cabang dan saluran utama.

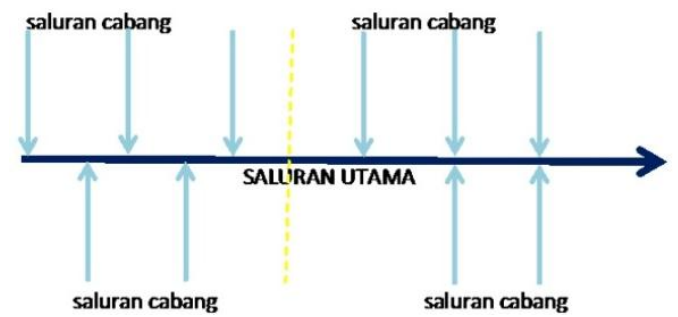

Gambar 8. Diagram jalur drainasi

Sumber: Hasil analisis, 2016

5. Penerapan sistem green roof pada atap bangunan yang berguna untuk menyerap sebagian besar air hujan yang jatuh di atap bangunan. Sistem ini bekerja secara pasif disaat hujan berlangsung sehingga air hujan tidak langsung dibiarkan mengalir menuju riol dan sungai.

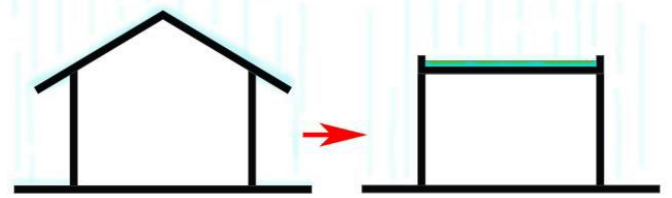

Gambar 9. Pembuatan green roof pada bangunan

Sumber: Hasil analisis, 2016

Tabel 1. Hubungan teori perancangan terhadap rainwater harvesting

\begin{tabular}{|c|c|c|c|}
\hline $\begin{array}{l}\text { Teori } \\
\text { Perancangan }\end{array}$ & $\begin{array}{l}\text { Teori } \\
\text { Rainwater } \\
\text { Harvesting }\end{array}$ & $\begin{array}{l}\text { Aktif/ } \\
\text { Pasif }\end{array}$ & $\begin{array}{l}\text { Lingkup } \\
\text { Kajian }\end{array}$ \\
\hline \multirow{2}{*}{$\begin{array}{l}\text { Tata guna } \\
\text { lahan }\end{array}$} & Storage & Aktif & Makro \\
\hline & $\begin{array}{l}\text { Jalur } \\
\text { drainase }\end{array}$ & Pasif & Makro \\
\hline Sirkulasi & $\begin{array}{l}\text { Celah } \\
\text { pembatas }\end{array}$ & Pasif & Mikro \\
\hline
\end{tabular}

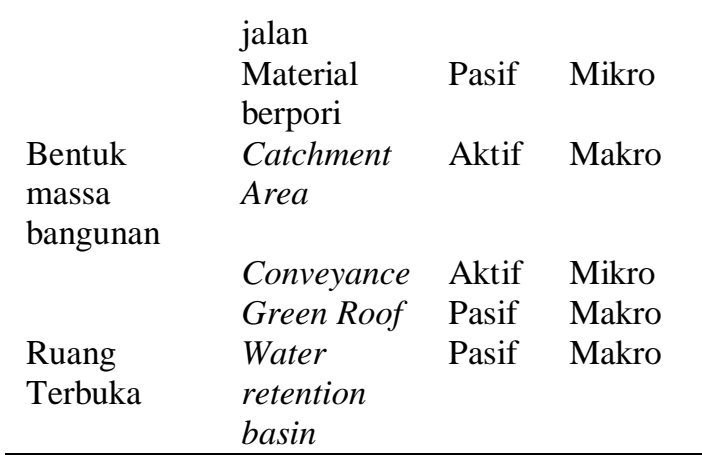

Sumber: Hasil analisis, 2016

Pertimbangan pertama atas pemilihan kawasan dilakukan berdasarkan beberapa pertimbangan, yaitu Tanah Abang merupakan salah satu wilayah kota di Jakarta yang dilalui aliran sungai besar yaitu Sungai Ciliwung. Permukiman yang berada di sekitar sungai pada kawasan Tanah Abang memberikan dampak buruk terhadap aliran Sungai Ciliwung. Tidak ada penerapan sistem pengolahan air hujan (rainwater harvesting) pada kawasan permukiman di wilayah Kebon Melati, Tanah Abang.

Kawasan Tanah Abang merupakan salah satu daerah di Kota Jakarta yang mempunyai kepadatan penduduk yang cukup tinggi. Hal tersebut menyebabkan daerah resapan air berkurang karena permukiman liar yang terus bertambah, khususnya di sepanjang tepi sungai Ciliwung yang melintasinya. Kawasan yang dijadikan objek penelitian memiliki luas sekitar $\pm 5,6$ Ha dengan daerah aliran sungai (DAS) seluas $\pm 1,1 \mathrm{Ha}$, sub zona taman kota yang berada di tiap sisi sungai seluas $\pm 2,1 \mathrm{Ha}$, dan wilayah permukiman warga seluas $\pm 2,4 \mathrm{Ha}$ dimana terdapat \pm 120 rumah tinggal (kepala keluarga) pada area batasan perancangan. 


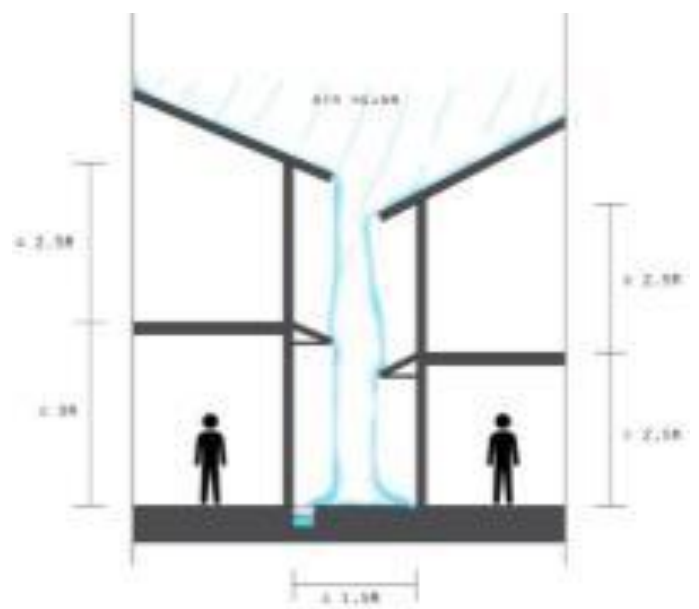

Gambar 10. Potongan rumah terhadap air hujan

Sumber: Hasil analisis, 2016

Berdasarkan Tabel 1, kawasan Tanah Abang belum mempunyai storage sebagai penyimpanan air hujan dan jalur drainase yang ada ditujukan untuk mengalirkan air hujan langsung menuju sungai. Celah pembatas pada jalan kawasan tidak berfungsi untuk mengalirkan air hujan menuju wilayah hijau melainkan menuju riol yang ada di sekitarnya. Atap bangunan di kawasan juga belum dirancang untuk menangkap air hujan, hanya digunakan sebagai pelindung dari sinar matahari. Kawasan Tanah abang juga belum mempunyai penerapan pada tiga bagian terakhir yaitu conveyance, green roof dan water retention basin.

Hasil perancangan ini berupa rancangan kawasan Kebon Melati, Tanah Abang dengan menerapkan sistem rainwater harvesting. Perancangan ini dibagi menjadi dua bagian yaitu rancangan kawasan dengan passive rainwater harvesting dan rancangan kawasan dengan active rainwater harvesting. Rancangan kawasan Kebon Melati ini mempunyai luas sekitar $\pm 5,6$ Ha dimana terdapat daerah aliran sungai (DAS) seluas $\pm 1,1 \mathrm{Ha}$, sub zona taman kota yang berada di tiap sisi Sungai Ciliwung seluas $\pm 2,1 \quad \mathrm{Ha}$, dan wilayah permukiman warga seluas $\pm 2,4 \mathrm{Ha}$ dimana terdapat \pm 120 rumah tinggal (kepala keluarga) pada area batasan perancangan.

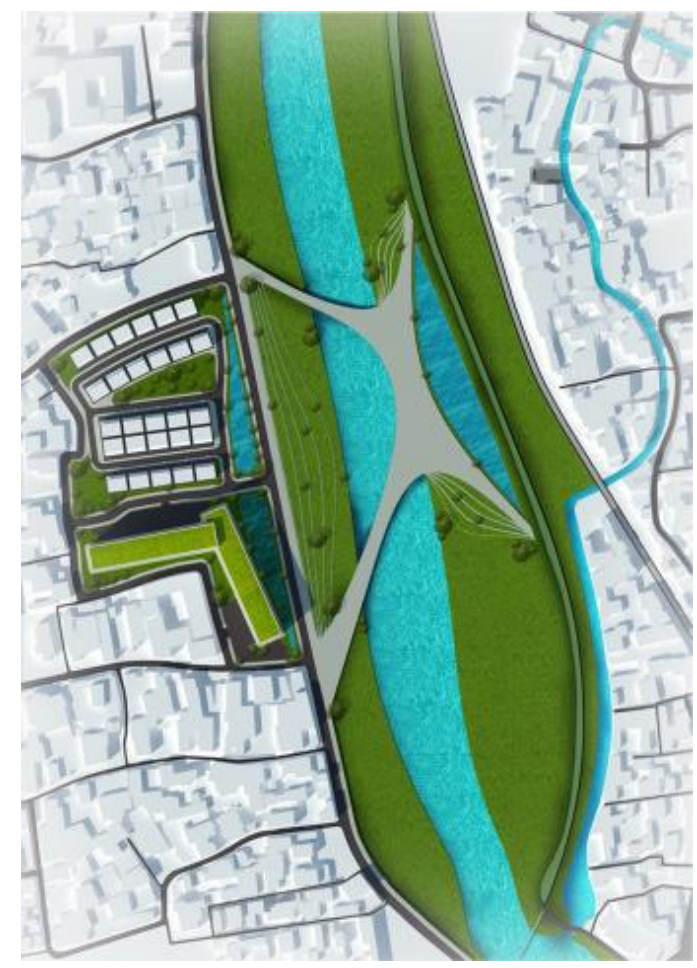

Gambar 11. Masterplan perancangan kawasan Tanah Abang

Sumber: Hasil analisis, 2016

Secara makro, perancangan kawasan dibuat memiliki dua storage terbuka yang masing-masing memadai tiap wilayah hunian. Storage (ditunjukan oleh warna biru pada Gambar 12) tersebut dirancang berdekatan langsung dengan sungai sebagai tujuan saluran dari seluruh wilayah bangunan. Sistem active rainwater harvesting yang diterapkan pada tata guna lahan berguna sebagai tempat penyimpanan / penampungan air hujan yang dapat diolah/digunakan untuk aktivitas manusia dalam bangunan. Contoh penggunaan air hujan tersebut pada 
aktivitas manusia adalah flushing toilet, mencuci baju, cooling tower, dan menyiram tanaman.

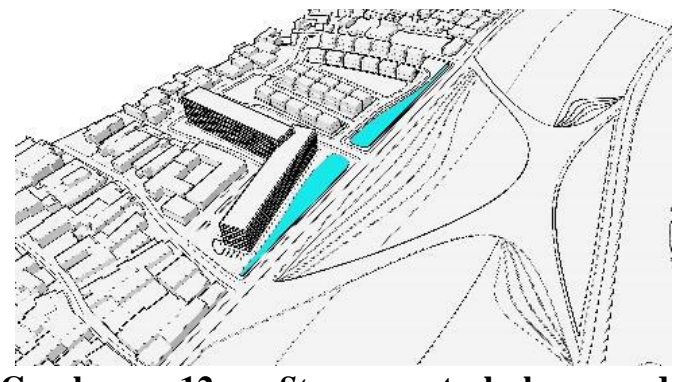

Gambar 12. Storage terbuka pada perancangan kawasan

Sumber: Hasil analisis, 2016

Pembuatan jalur drainase tambahan pada kawasan berfungsi untuk memperlambat aliran air hujan yang mengalir menuju sungai. Di dalam perancangan ini jalur drainase dibagi menjadi dua saluran drainase yaitu saluran cabang yang menghubungkan antar bangunan dalam permukiman dan saluran utama di sepanjang jalan raya yang menghubungkan seluruh saluran cabang dan mengalirkan air menuju sungai (ditnjukkan oleh warna ungu pada Gambar 13).

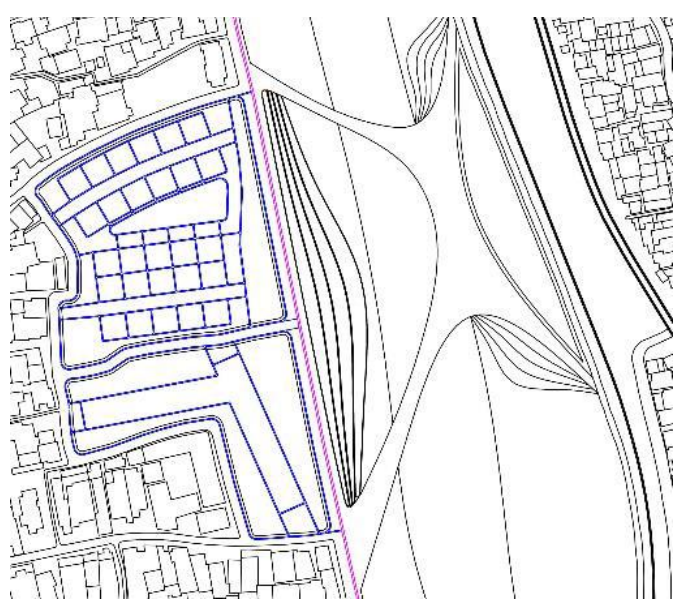

Gambar 13. Pembagian jalur drainase pada perancangan kawasan

Sumber: Hasil analisis, 2016
Pembuatan jalur drainase dibagi menjadi dua wilayah yaitu wilayah hunian dan jalan raya utama yang berada dekat dengan sungai. Saluran cabang yang ada pada wilayah hunian dibuat saling berhubungan antar massa bangunan sehingga air hujan dapat tertampung sementara selama mengalir melalui jalur drainase yang saling berhubungan. Sedangkan jalur drainase saluran utama dibuat di sepanjang jalan utama sehingga dapat menghubungkan seluruh saluran cabang sebelum dialirkan menuju Sungai Ciliwung yang ada di sampingnya.

Catchment area diterapkan pada seluruh atap bangunan sehingga setiap bangunan dapat menampung air hujannya masingmasing. catchment area yang terdapat pada kawasan dibagi menjadi dua yaitu pada bagian atap bangunan dan permukaan jalan/tanah yang terdapat dalam lingkup kawasan. Penerapan sistem green roof diterapkan pada bangunan yang memiliki penampang atap yang paling luas yaitu bangunan $\mathrm{d}$ bagian selatan berbentuk huruf L. Sistem passive rainwater harvesting yang diterapkan pada bentuk dan massa bangunan ini bertujuan untuk menyerap dan menampung air hujan sementara yang jatuh pada atap bangunan. Selebihnya, air akan disalurkan melalui conveyance

menuju storage pada kawasan. Penerapan sistem green roof pada kawasan di pilih berdasarkan luas atap pada massa bangunan. Pada perancangan kawasan ini, bangunan berupa rumah susun (perumahan vertikal) merupakan massa bangunan yang mempunyai luas atap sebesar $\pm 2520 \mathrm{~m} 2$ dimana luas tersebut lebih besar dibandingkan dengan bangunan

di wilayah perumahan sedang yang mempunyai luas atap $\pm 120 \mathrm{~m} 2$ tiap 
rumah. Dari perbandingan luas atap tersebut, sistem green roof ini diterapkan pada bangunan rumah susun (perumahan vertikal).

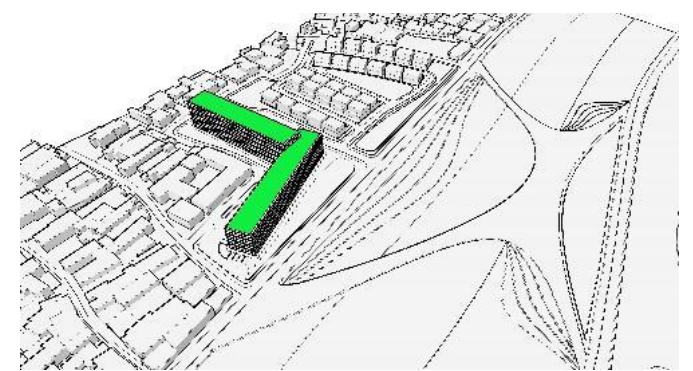

Gambar 14. Penerapan green roof pada bangunan dengan penampang atap terluas Sumber: Hasil analisis, 2016

Dan untuk mengantisipasi meluapnya air pada sungai disediakan penampungan air tambahan di samping sungai. Sistem passive rainwater harvesting yang diterapkan berupa pembuatan tempat penampungan air tambahan. Sistem ini hampir sama seperti storage, bedanya adalah water retention basin yang diterapkan bertujuan untuk menampung air hujan sementara pada zona taman kota sehingga volume air hujan yang harus ditampung Sungai Ciliwung dapat berkurang. Pembuatan tempat penampungan air tambahan (water retention basin) dilakukan pada zona taman kota di sisi timur Sungai Ciliwung. Hal tersebut bertujuan untuk menjadikan tempat penampungan air tersebut sebagai batas antara zona hijau taman dan zona hijau pengaman jalur kereta api. Selain itu, dengan adanya kolam tambahan (tempat penampungan air) dapat memberikan interaksi lebih bagi taman kota terutama jembatan yang ada.

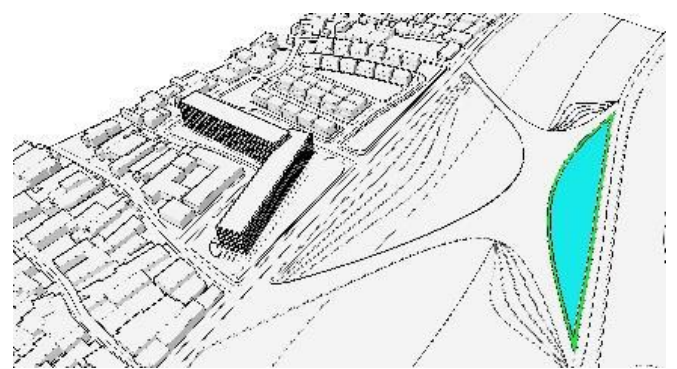

Gambar 15. Penyediaan penampang air pada saat kuota hujan berlebih pada musimnya Sumber: Hasil analisis, 2016

Sistem passive rainwater harvesting pertama yang diterapkan pada sirkulasi kendaraan dan jalur pejalan kaki ini adalah pembuatan celah pada pembatas antara jalan dengan wilayah hijau. Hal ini bertujuan untuk mengurangi resiko banyaknya genangan air hujan pada permukaan serta memperlambat proses mengalirnya air hujan menuju sungai.

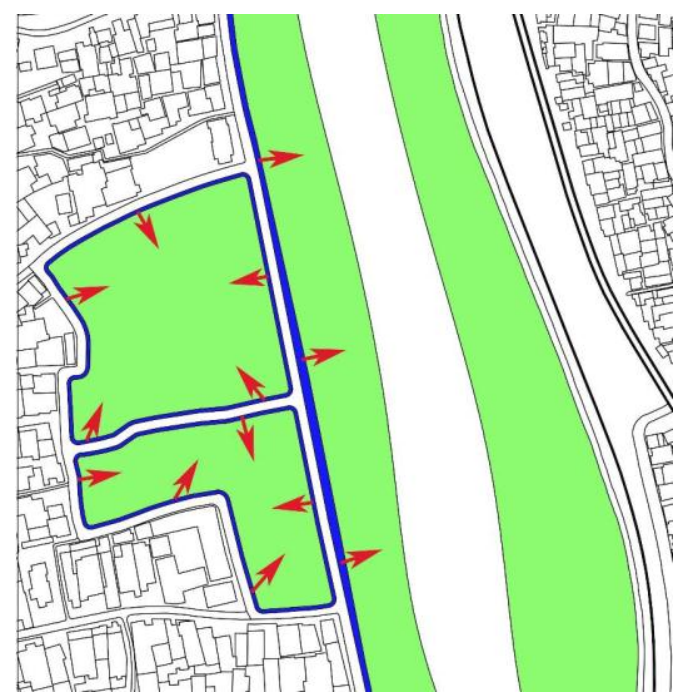

Gambar 16. Pemetaan celah pada pembatas jalan di perancangan kawasan

Sumber: Hasil analisis, 2016

Pada gambar 16, dapat dilihat bahwa hampir seluruh jalur pejalan kaki bersebelahan dengan wilayah hijau/lansekap yang ada pada kawasan. Karena hal tersebut, pembuatan celah antara pembatas jalan dan wiayah hijau dapat diterapkan guna mengalirkan 
langsung air hujan yang jatuh pada permukaan jalan menuju wilayah hijau untuk diserap dan ditampung sementara. Gambar 17 merupakan contoh penerapan sistem ini pada jalur pejalan kaki.

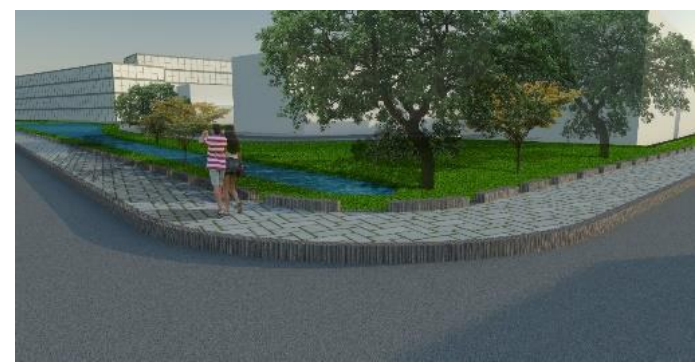

Gambar 17. Penerapan celah pada pembatas dan material berpori pada rancangan

Sumber: Hasil analisis, 2016

Sistem passive rainwater harvesting kedua yang diterapkan pada sirkulasi kendaraan dan jalur pejalan kaki ini memiliki fungsi yang sama dengan pembuatan celah pada pembatas jalan. Bedanya adalah sistem ini bisa diterapkan langsung pada permukaan yang cukup luas dan jauh dari wilayah hijau. material berpori pada perancangan diterapkan pada jalur pejalan kaki. Hal tersebut bertujuan untuk mengurangi resiko terhadap genangan air hujan yang jatuh pada jalur pejalan kaki apabila wilayah hijau/lansekap di sekitarnya tidak dapat menampung air hujan lagi yang dialirkan dari jalan melalui celah yang ada pada pembatas jalan.

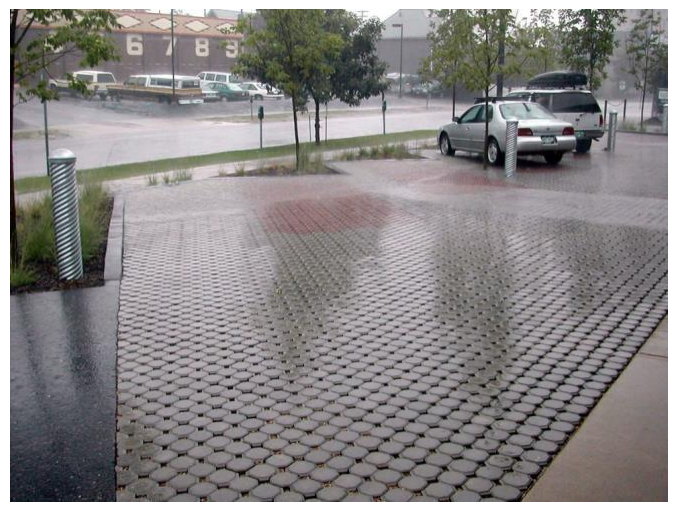

Gambar 18. Contoh material berpori pada permukaan jalan

Sumber: https://s-media-cache-ak0.pinimg.com

\section{Kesimpulan}

Sistem rainwater harvesting dapat diterapkan pada sebuah kawasan permukiman yang berada dekat dengan sungai dimana sistem tersebut dapat berfungsi dengan dasar pengolahan air hujan. Perancangan kawasan dengan sistem rainwater harvesting secara aktif maupun pasif merupakan sebuah hal yang dibutuhkan dalam kota, khususnya wilayah permukiman yang berada di dekat sungai.

Di dalam proses perancangan terdapat kajian teori/studi literatur yang digunakan sebagai pedoman dalam tahap analisis tapak dan proses perancangan. Studi literatur pertama mencakup teori perancangan kota yaitu tata guna lahan (land use), sirkulasi kendaraan, bentuk dan massa bangunan, ruang terbuka, dan jalur pejalan kaki. Literatur kedua mencakup teori active rainwater harvesting yaitu catchment area, conveyance, dan storage. Literatur ketiga mencakup teori passive rainwater harvesting yaitu water retention basin, celah pada pembatas jalan, material berpori, jalur drainase, dan green roof.

Analisis tapak pada kawasan Kebon Melati merupakan salah satu proses dalam perancangan. Hal ini bertujuan untuk mengetahui kondisi dan permasalahan umum pada tapak, dampak - dampak yang dihasilkan oleh wilayah permukiman warga terhadap salah satu sungai besar yang melintasi kawasan yaitu Sungai Ciliwung, menganalisis kawasan berdasarkan teori dasar perancangan kota dan sistem 
rainwater harvesting aktif dan pasif, serta mengetahui potensi - potensi yang dapat dimanfaatkan/dikembangkan dalam perancangan.

Konsep utama dalam perancangan ini adalah merancang kembali kawasan permukiman Kebon Melati dengan mempertimbangkan kondisi tapak, potensi, dan dampak yang dihasilkan terhadap lingkungan sekitarnya. Perancangan terhadap kawasan permukiman yang berada dekat dengan sungai di dalam kota mempunyai potensi dalam penerapan sistem rainwater harvesting terutama sistem yang bersifat makro dan pasif dimana kawasan dirancang untuk membantu sungai dalam menampung air sementara dan memperlambat aliran air ketika hujan berlangsung.

Hasil perancangan kawasan dijelaskan dalam bentuk diagram beserta gambar gambar perancangan seperti blockplan, potongan, dan perspektif suasana hasil rancangan kawasan. Hasil rancangan pada kawasan dengan sistem rainwater harvesting ini dapat dijadikan sebagai contoh dalam merancang kawasan permukiman di dalam kota, karena dengan padatnya jumlah penduduk dalam kota kebutuhan akan air juga semakin meningkat sehingga pengolahan air hujan dapat menjadi salah satu solusi untuk mendapatkan sumber air bersih dan mencegah mencegah resiko meluapnya sungai akibat besarnya kapasitas air yang dihasilkan oleh hujan dalam kawasan itu sendiri.

\section{Daftar Pustaka}

Adeyeye, Kemi. (2013). Water Efficiency in Buildings: Theory and Practice. United Kingdom: John Wiley \& Sons, Ltd.

Angelakis, Andreas N., Rose, Joan B. (2014). Evolutions of Sanitation and Wastewater Technologies through the Centuries. London: IWA Publishing.

Berardi, Umberto. (2013). Moving to sustainable buildings: paths to adopt green innovations in developed countries. London: Versita.

Bianpoen. (2011). Untuk apa? Untuk siapa? : rangkaian pemikiran lingkungan berkelanjutan. Tangerang: UPH Press.

Booth, A. Colin., and Charlesworth M., Susanne. (2014). Water Resources in the Built Environment: Management Issues and Solutions. United Kingdom: John Wiley \& Sons, Ltd.

Chandrappa, Ramesha. (2014). Sustainable Water Engineering: Theory and Practice. United Kingdom: John Wiley \& Sons, Ltd.

Grant, Gary. (2016). The Water Sensitive City. United Kingdom: John Wiley \& Sons, Ltd.

Kinkade-Levario, Heather. (2007). Design for water: rainwater harvesting, stormwater catchment, and alternate water reuse. Gabriola Island, B.C.: New Society Publishers.

Novak, Celeste Allen., Eddie Van Giesen, and Kathy M. DeBusk. (2014). Designing rainwater harvesting systems: integrating rainwater into building systems. Hoboken, NJ: Wiley.

Shirvani, Hamid. (1985). The urban design process. Chapman \& Hall. 
Jurnal Teknik Arsitektur ARTEKS, Volume. 2, Nomor 2, Desember 2017 ISSN 2541-0598 